\title{
New Genera of Foraminifera Identified for the Upper Badenian Deposits to the North-Eastern Part of the Moldavian Platform
}

\author{
Bogdan-Adrian Ispas \\ Department of Geology, Faculty of Geography and Geology, “Alexandru Ioan Cuza” University of Iaşi, Iaşi 700505, Romania
}

\begin{abstract}
In the North-East of the Moldavian Platform, the upper Badenian is composed of three lithologic units, on top of which there is Limestones and Marls with Lithothamnium Formation. At the level of this formation, the geological research conducted in four localities near the Prut Valley demonstrated, based on two new foraminifera genera identified in this area-Oolina and Velapertina - favorable conditions for the development of the stenohaline fauna, a marine shelf environment with warm water, as well as the certitude regarding the age of the late Badenian for these. These results were not previously reported in this area.
\end{abstract}

Key words: Foraminifera, Moldavian Platform, upper Badenian, biostratigraphy, paleoecology.

\section{Introduction}

This study is based on the geological research carried out in the upper Badenian from the North-East of the Moldavian Platform, at the level of the Supraanhydritic Formation (Limestones and Marls with Lithothamnium) of an outcrop from Crasnaleuca, on 3 drillings executed to Trușești-Drislea, Hlipiceni, Şipote (Fig. 1) and on the identification, in this area, of 2 new genera: Oolina and Velapertina.

The upper Badenian deposits of the Supraanhydritic Formation crop out in the Romanian territory, in the North-East of the Moldavian Platform, in the Prut Valley, being studied by various researchers, especially in the last century. In a geological study on the Prut Valley area from the North-East of the Moldavian Platform, Simionescu [1] identified, near Crasna-leuca, the deposits of the Limestones and Marls with Lithothamnium Formation and determined a bivalve fauna.

At Crasnaleuca, Ionesi [2] signaled the

Corresponding author: Bogdan-Adrian Ispas, Ph.D. student, research fields: micropaleontology, paleontology and paleoecology. E-mail: bogdan.ispas@student.uaic.ro.
Badenian/Sarmatian boundary and determined, at the level of Limestones and Marls with Lithothamnium Formation, a rich fauna of foraminifera, ostracods, bryozoans, bivalves etc.

L. Ionesi and B. Ionesi [3] carried out a geological profile at Grimeşti bend (Crasnaleuca), in which they present the Cenomanian/Badenian and Badenian/Sarmatian (Buglovian) contacts.

The drillings executed to Trușești-Drislea, Hlipiceni and Șipote were studied from the point of view of lithology, micro- and macro-fauna, in a study by Ref. [4]. Also, in Trușești (Trușești-Drislea) and Șipote drillings, Brânzilă and Chira [5] highlighted the Badenian/Sarmatian contact, based on molluscs, foraminifera and nannoplankton.

\section{Geology of the Studied Area}

The upper Badenian crops out in the North of the Moldavian Platform, between Oroftiana de Sus and Liveni, localities situated on the Prut Valley [6] and, in terms of lithology, it comprises three units: the Detrital or Infraanhydritic Formation, the Evaporitic Formation, and the Calcareous Marl Clay or the Supraanhydritic Formation [3, 7]. The last lithologic 


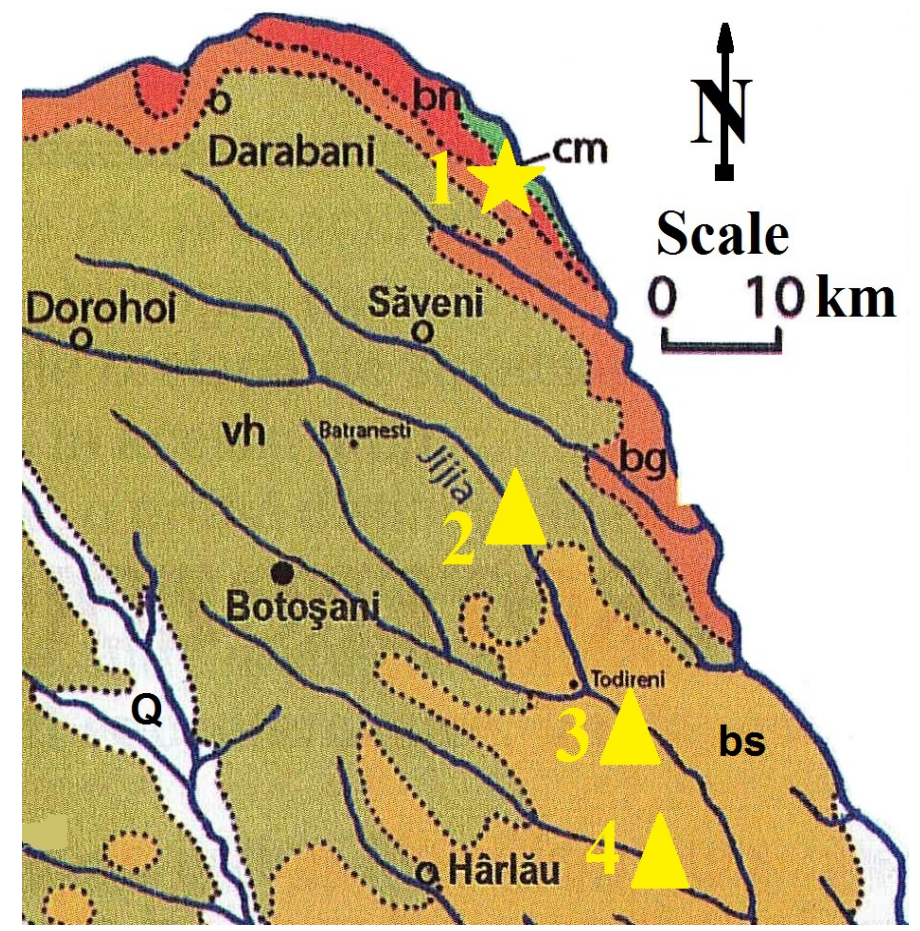

Fig. 1 Location of micropaleontological samples (map taken from Ref. [6]): 1-Crasnaleuca; 2-Trușești-Drislea; 3-Hlipiceni; 4-Şipote. The abbreviations mean: cm-Cenomanian; bn-Badenian; bg-Buglovian; vh-Volhynian; bs-Bessarabian; Q-Quaternary.

unit is represented in the North-East of the Moldavian Platform by deposits consisting of Limestones and Marls with Lithothamnium, which grow in thickness with the approach to the Carpathian orogen [7].

This stratigraphic substage is part of the last sedimentation cycle of the Moldavian Platform, upper Badenian-Meotian [7], and it is characterized by a rich and diverse stenohaline fauna, represented by bivalves, gastropods, foraminifera, ostracods, bryozoans etc. The presence of these organisms explains a marine regime with a normal salinity, a high oxygen content $[4,8]$, as well as the conditions of a warm sea [9].

\section{Materials and Methods}

The main tools used in performing the present study consisted of a Picard hammer, a soffit, a Nikon Coolpix S2500 camera, a weighing, 3 standard analytical sieves, a \#204 Celestron professional microscope and micropaleontological cells.

The collected samples were processed in the laboratory of Geology and Paleontology of the Faculty of Geography and Geology, by standard micropaleontological methods. The identified taxons were photographed at the electron microscope of the Faculty of Biology, within the "Alexandru Ioan Cuza" University.

From the samples taken for micropaleontological analyses, Oolina taxons were identified to Crasnaleuca (1 sample, Fig. 2), Trușești-Drislea (1 sample, Fig. 3), Hlipiceni (1 sample, Fig. 3) and Şipote (2 samples, Fig. 3), and Velapertina taxons in the S1 sample, from the Șipote drilling (Fig. 3).

The analyzed samples were also used in a far more complex micro-paleontological study [10].

\section{Significance of Analyzed Microfauna}

The Oolina genus d'Orbigny, 1839 (Fig. 4) has been identified in all mentioned collection points; it has a low frequency in the foraminifera assemblage identified in the area and it indicates a marine shelf environment. It has a globular-oval, unilocular, 


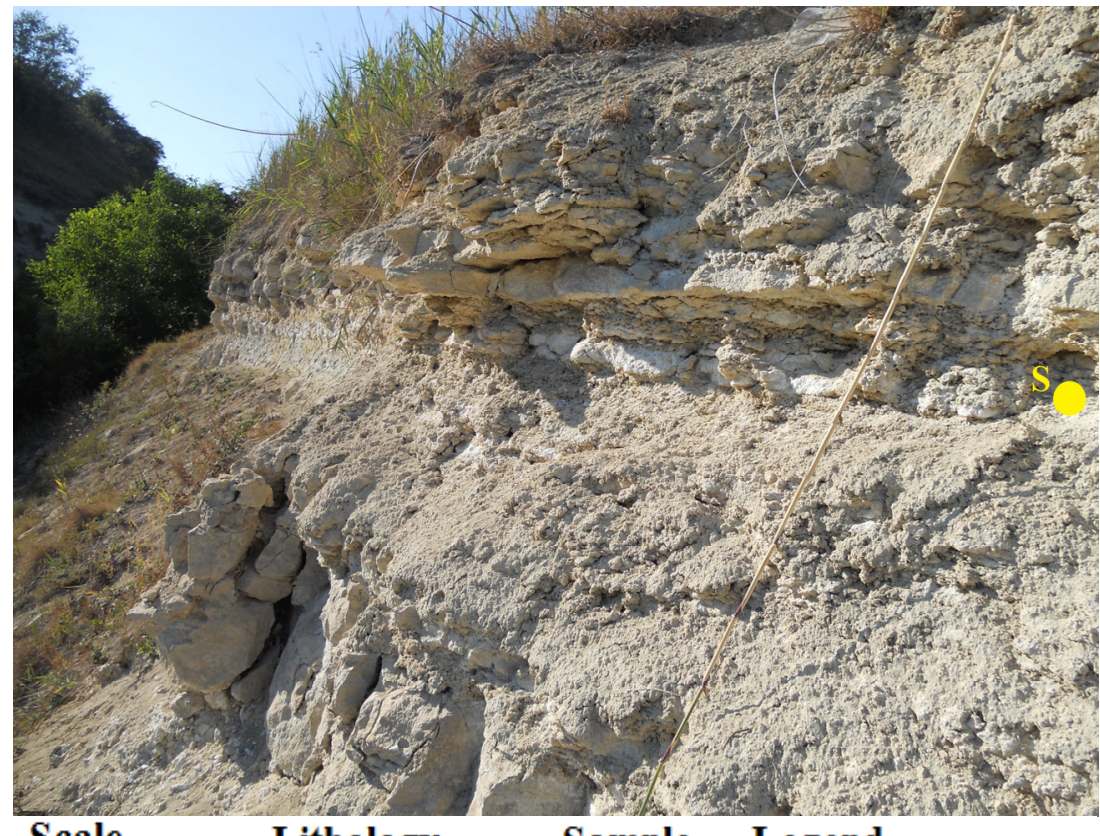

\section{Scale \\ Lithology}

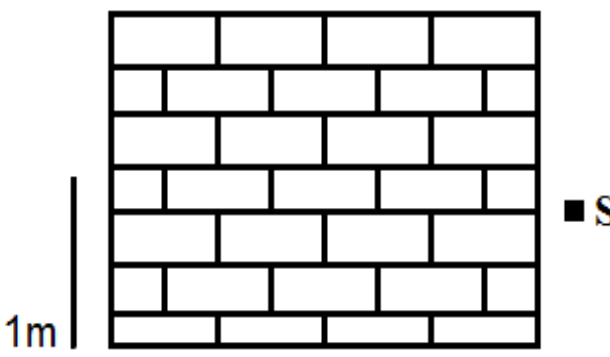

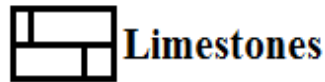

\section{$\mathbf{S}$}

Fig. 2 Image and lithological column of the outcrop from Crasnaleuca (after Ref. [10], modified).

hyaline, calca-reous and smooth test and it occupies a large stratigraphic interval, from the Jurassic to the Holocene [11]. The species of Oolina (Fig. 4) identified in this area are new for Science, because I did not find them in other specialized sudies.

It is spread in the Eastern Paratethys [12], in the Central Paratethys [13-18], as well as in other basins around the Globe [19-22].

The Velapertina genus Popescu, 1969 (Fig. 5) also has a low frequency in the microfauna assemblage, being present in the S1 sample of the Sipote drilling. It features a subglobular test, with perforated calcareous wall [11]. It is planktonic and it indicates a warm water marine envi-ronment [23]. In terms of stratigraphy, it represents an index taxon for the Upper Badenian [24]. I think that the species of Velapertina
(Fig. 5) from the studied area are new for Science, because I did not find them in other specialized sudies.

The distribution area of the Velapertina genus constitutes the Eastern and the Central Paratethys [23, 25-27], as well as other regions [28, 29].

\section{Conclusions}

The geological research conducted in North-East of the Moldavian Platform, at the level of the Supraanhydritic Formation of the upper Badenian, revealed new foraminifera genera for this area: Oolina and Velapertina. The samples for micropaleontological analyses taken from the Crasnaleuca outcrop and from the drillings carried out at Trușești-Drislea, Hlipiceni and Şipote identified a fora-minifera assemblage, in which the new mentioned genera have a low weight. 
New Genera of Foraminifera Identified for the Upper Badenian Deposits to the North-eastern Part of the Moldavian Platform

\section{Scale Well depth Lithology Sample Legend}
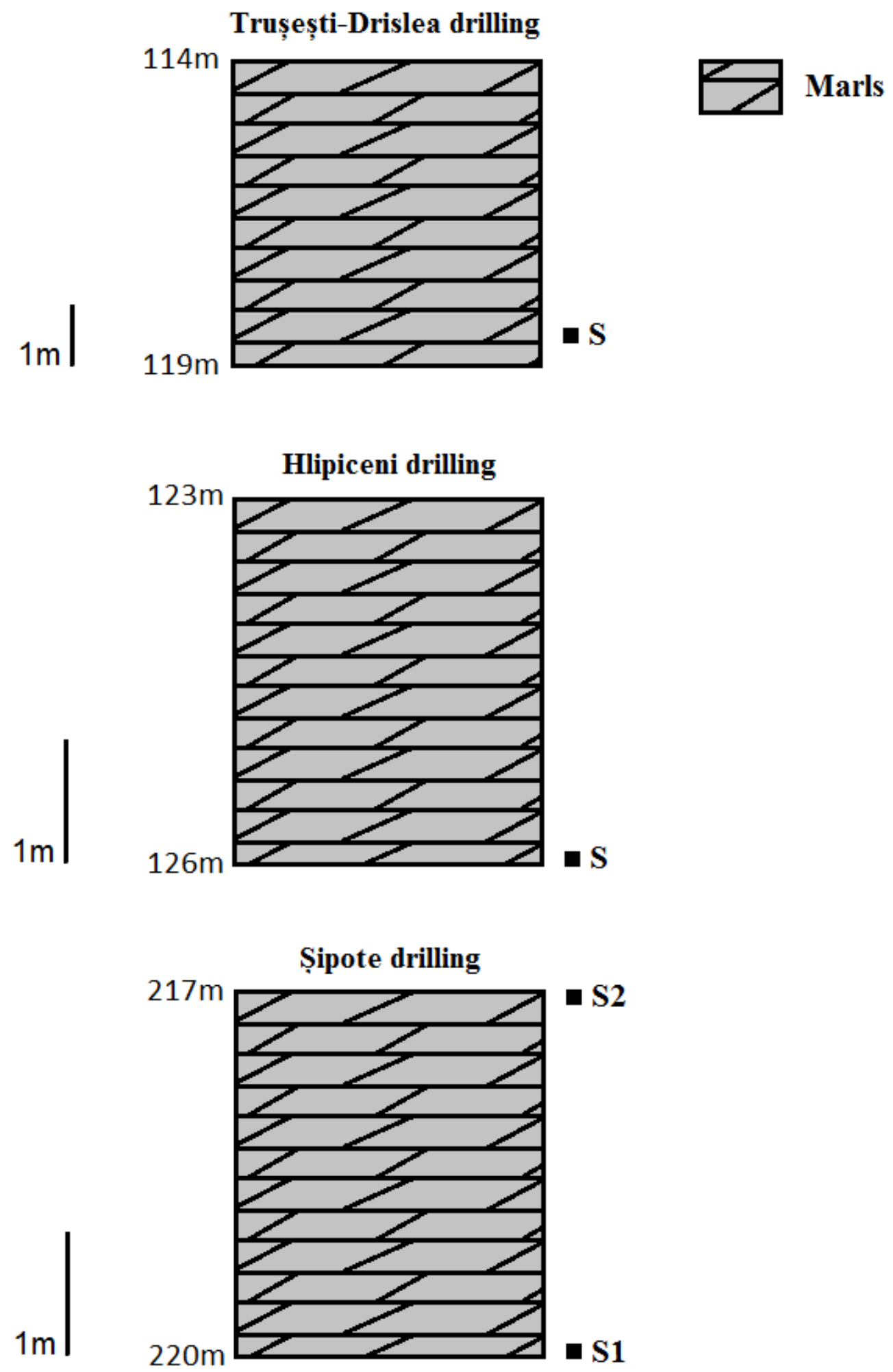

Fig. 3 Lithological columns of Trușești-Drislea, Hlipiceni and Șipote drillings (after Ref. [10], modified). 

North-eastern Part of the Moldavian Platform

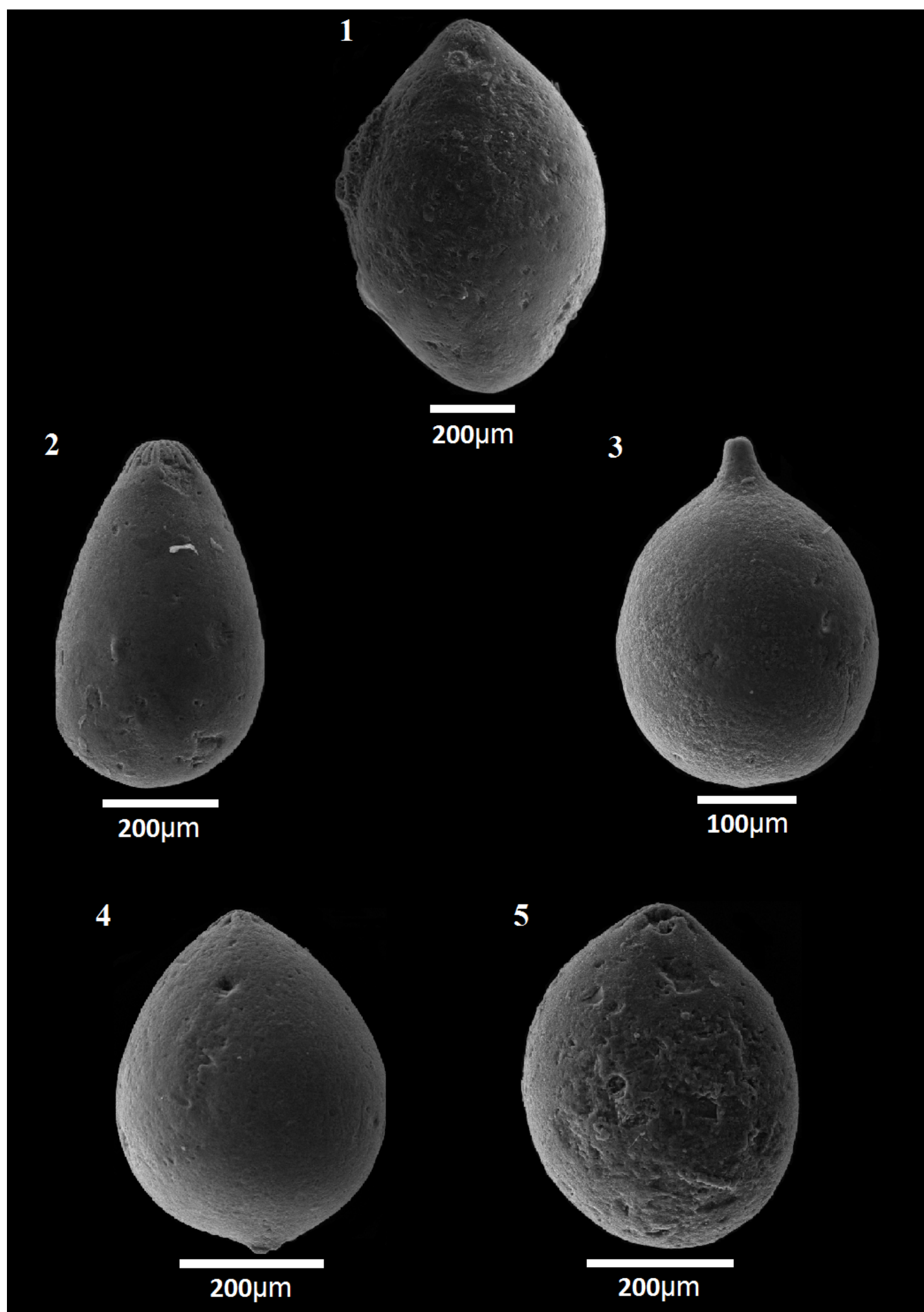

Fig. 4 Oolina n. sp.: 1 (from Hlipiceni drilling); 2-4 (from S1 sample of Şipote drilling)—2 is also illustrated in Ref. [10]; 5 (from S2 sample of Şipote drilling). 

North-eastern Part of the Moldavian Platform

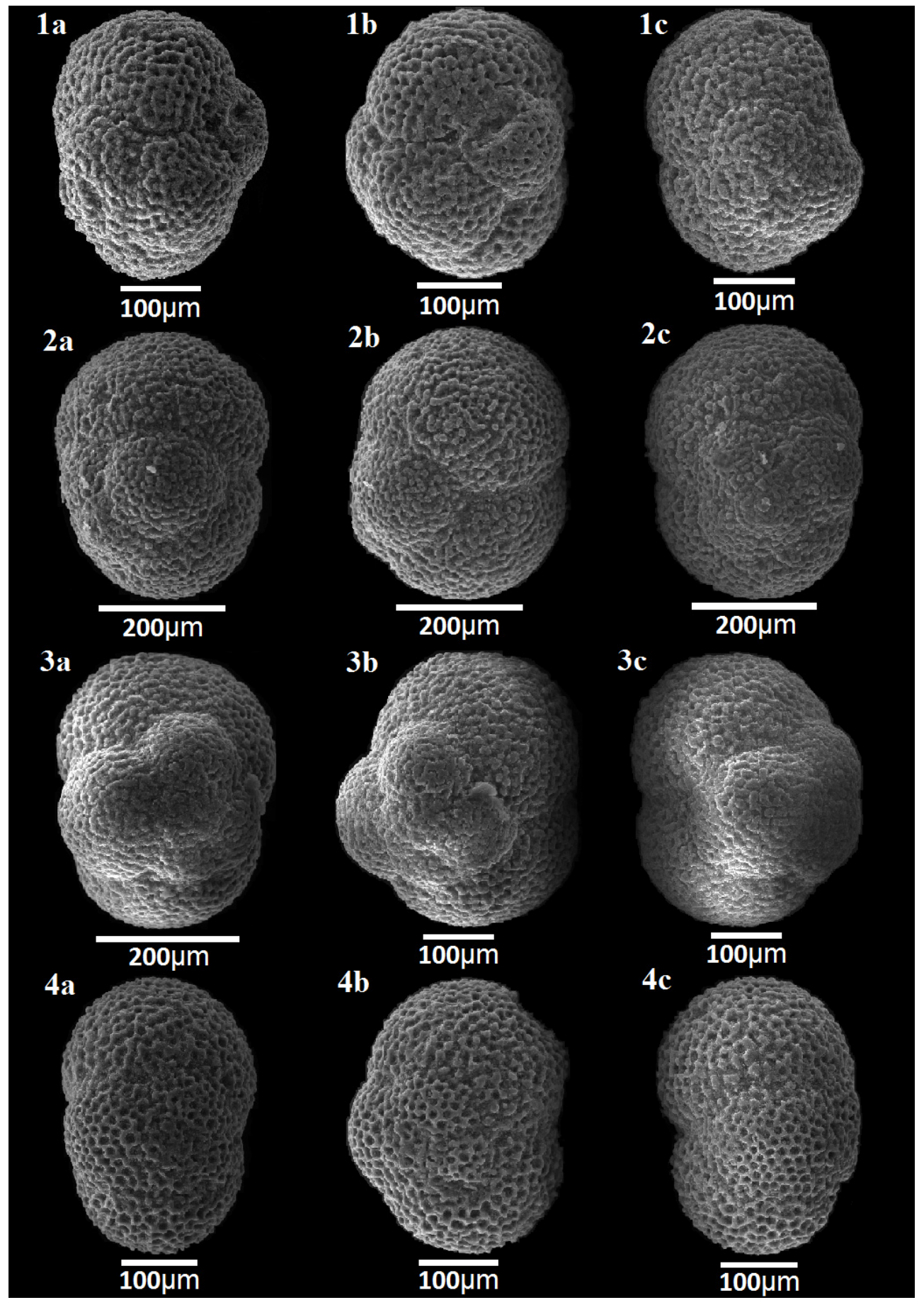

Fig. 5 Velapertina n. sp. (from S1 sample of Șipote drilling) - 1a-1c is also illustrated in Ref. [10].

However, the taxonomic and paleo-ecological importance that the Oolina genus presents, as well as the stratigraphic value of the Velapertina genus, prove the upper Badenian age of the deposits from which the samples were taken and favorable marine conditions for the development of the stenohaline fauna.

\section{Acknowledgements}

I would like to thank Professor Dr. Mihai Brânzilă, for the theoretical and the practical support in completing this study and for providing the material 

North-eastern Part of the Moldavian Platform

for micropaleontological analyses from the drillings carried out at Trușești-Drislea, Hlipiceni, Șipote, and also to Conferrer Dr. Viorel Ionesi, for the help offered in identifying the Velapertina taxons.

\section{References}

[1] Simionescu, I. 1902. "Geological Constitution of the Prut Shore from the Northern Moldova." Acad. Rom. Rev. Fond. șt. "V. Adamachi”, II, București. (in Romanian)

[2] Ionesi, B. 1977. "Contributions about BadenianSarmatian Boundary from Moldavian Platform.” An. Șt. Univ. “Al. I. Cuza”, secț. II.b. (Geol.-Geogr.), T. XXIII, Iași. (in Romanian)

[3] Ionesi, L., and Ionesi, B. 1981. "New Data about the Sarmatian from the North-Eastern Moldavian Platform (Hudești-Mitoc Reg.).” Acad. Rom. Mem. secț. șt. seria IV, T. IV/1, București. (in Romanian).

[4] Brânzilă, M. 1999. "Geology of the Southern Moldavian Platform.” Ed. Corson, Iași. (in Romanian)

[5] Brânzilă, M., and Chira, C. 2005. "Microfossils Assemblages from the Badenian/Sarmatian Boundary in Boreholes from the Moldavian Platform." Acta Palaeontologica Romaniae v. 5: 17-26.

[6] Mutihac, V., and Mutihac, G. 2010. "Geology of Romania in the Central-Eastern-European Geostructural Context.” Ed. Didactică și Pedagogică, București. (in Romanian)

[7] Ionesi, L. 1994. "Geology of Platform Units and North Dobrogea Orogen.” Editura Tehnică, București. (in Romanian)

[8] Paghida-Trelea, N. 1969. "Microfauna of the Miocene between Siret and Prut." Ed. Acad. Rom., București. (in Romanian)

[9] Ionesi, B. 1968. "Stratigraphy of Miocene Platform Deposits between Siret Valley and Moldova Valley." Ed. Acad. Rom., București. (in Romanian)

[10] Ispas, B. A. 2016. "The Reconstruction of the Sedimentation Paleoenvironments at the Badenian/ Sarmatian Boundary, from the North-East of the Moldavian Platform, based on Foraminifera Fauna.” Ph.D. thesis. “Al. I. Cuza” Univ. Iași. (in Romanian)

[11] Bucur, I., and Filipescu, S. 1999. "Foraminifera Micropaleontology.” Editura Presa Universitară Clujeană. (in Romanian)

[12] Varentsov, I. M., Muzyliov, N. G., Nikolaev, V. G., and Stupin, S. I. 2003. "The Origin of Black Shale-Hosted Mn Deposits in Paratethyan Basins: Constraints from Geological Events at the Eocene/Oligocene Boundary." Russian Journal of Earth Sciences 5 (4): 255-72.

[13] Báldi, K., and Hohenegger, J. 2008. "Paleoecology of
Benthic Foraminifera of the Baden-Sooss Section (Badenian, Middle Miocene, Vienna Basin, Austria).” Geologica Carpathica 59 (5): 411-24.

[14] Peryt, D., and Peryt, T. M. 2015. "Environmental Changes Prior to and at the Beginning of Deposition of the Badenian Gypsum (Wschodnia River Region, Northern Part of the Fore-Carpathian Basin).” Bulletin Geological Institute 461: 133-52.

[15] Peryt, D., and Dubicka, Z. 2009. "Palaeo Environmental Changes in the Early Maastrichtian of the Nida Trough (Southern Poland): Foraminiferal Evidence." In Seventh Micropalaeontological Workshop, Mikro-2009 (OEw. Katarzyna, Poland, September 28-30, 2009), Abstracts and Excursion Guide, edited by Peryt, D., and Kaminski, M. A. Grzybowski Foundation Special Publication, 114.

[16] Pezelj, D., Mandic, O., and Ćorić, S. 2013. "Paleoenvironmental Dynamics in the Southern Pannonian Basin during Initial Middle Miocene Marine Flooding." Geologica Carpathica 64 (1): 81-100.

[17] Silye, L. 2015. Sarmatian Foraminiferal Assemblages from Southern Transylvanian Basin and Their Significance for the Reconstruction of Depositional Environments. Cluj-Napoca: Presa Universitară Clujeană.

[18] Suciu, A. A. 2002. "Some Micropaleontological Data Indicating the Presence of (Lower and Upper) Badenian at Cluj-Napoca (Romania)." Studia Universitatis Babeș-Bolyai, Geologia XLVII (2): 63-74.

[19] Atif, K. F. T., Bessedik, M., Belkebir, L., Mansour, B., and Saint Martin, J.-P. 2008. "The Passage Mio-Pliocene in the Basin of the Lower Chelif (Algeria). Biostratigraphy and Paleoenvironmental." Geodiversitas 30 (1): 97-116.

[20] Aturamu, A. O. 2015. "The Palaeontology of Bering Sea Foraminifera from the Late Quaternary." Thesis submitted for the degree of Doctor of Philosophy at the University of Leicester.

[21] Ismail, A. A., and Abdelghany, O. 1999. "Lower Miocene Foraminifera from Some Exposures in the Cairo-Suez District, Eastern Desert, Egypt." Journal of African Earth Sciences 28 (3): 507-26.

[22] Spezzaferri, S., and Tamburini, F. 2007. "Paleodepth Variations on the Eratosthenes Seamount (Eastern Mediterranean): Sea-Level Changes or Subsidence?" eEarth Discussions 2:115-32.

[23] Kováč, M., Andreyeva-Grigorovich, A., Bajraktarević, Z., Brzobohatý, R., Filipescu, S., Fodor, L., Harzhauser, M., Nagymarosy, A., Oszczypko, N., Pavelić, D., Rögl, F., Saftić, B., LUbomir, S., and Studencka, B. 2007. "Badenian Evolution of the Central Paratethys Sea: Paleogeography, Climate and Eustatic Sea-Level Changes." Geologica Carpathica 58 (6): 579-606.

[24] Popescu, Gh. 1995. "Contribution to the Knowledge of 


\section{North-eastern Part of the Moldavian Platform}

the Sarmatian Foraminifera of Romania." Rom. J. Paleontology 76: 85-98.

[25] Paruch-Kulczycka, J. 2015. "Foraminiferal Biostratigraphy of the Miocene Deposits from the Busko (M£yny) PIG-1 and Kazimierza Wielka (Donosy) PIG-1 Boreholes (Northern Part of the Carpathian Foredeep)." Biuletyn Państwowego Instytutu Geologicznego 461: 115-32.

[26] Szczechura, J. 1984. "Morphologic Variability in the Globigerinoides-Orbulina Group from the Middle Miocene of the Central Paratethys." Acta Palaeontologica Polonica 29 (1-2): 3-27; 1-11.

[27] Vrsaljko, D., Pavelić, D., Miknić, M., Brkić, M., Kovačić,
M., Hećimović, I., Hajek-Tadesse, V., Avanić, R., and Kurtanjek, N. 2006. "Middle Miocene (Upper Badenian/ Sarmatian) Palaeoecology and Evolution of the Environments in the Area of Medvednica Mt. (North Croatia)." Geologia Croatica 59/1: 51-63.

[28] Islamoğlu, Y., and Taner, G. 2003. "The Paleogeographic and Paleoecologic Characteristics of the Miocene aged Molluscan Fauna in Antalya and Kasaba Basins (West-Central Taurus, SW Turkey)." Mineral Res. Expl. Bull 126: 11-42.

[29] Liska, R. D. 1991. "The History, Age and Significance of the Globorotalia Menardii Zone in Trinidad and Tobago,West Indies." Micropaleontology 37 (2): 173-82. 